\title{
11. Clashing Perspectives: Cannabis Users and Swedish Drug Policy
}

Josefin Månsson, Mats Ekendahl \& Patrik Karlsson

\section{Introduction}

Urine testing wasn't fun. I mean, they are so advanced now, they see the THC [tetrahydrocannabinol] count go up and down. Not only if it's a positive or a negative, but to what extent. It was hard, because I thought that they would only detect if it was a positive or a negative, and that I could smoke a little while tapering off. But all along it went up and down... They called it a relapse when I came in for a meeting: 'You've had a relapse!' Oh my god, such a hassle. I just smoked a joint.

(Hektor)

Hektor was a cannabis smoker in his twenties who had been in treatment for some time back when we met with him for an interview. He told us that he liked to smoke cannabis, but that he wanted to stop using it while he was in treatment since his school required this. The above quote is an extract from his story about meeting the Swedish youth treatment system. Just like many other cannabis users we have talked to, Hektor's story about his own use, what cannabis meant to him and how he experienced and calculated risks differed from what the treatment staff had told him about cannabis. By emphasizing the silliness of denoting smoking a joint with the clinical term relapse, he points to this fundamental conflict between perspectives.

It is against this background that we have found it interesting to study different perspectives on cannabis use and what happens

How to cite this book chapter:

Månsson, Josefin, Ekendahl, Mats and Karlsson, Patrik. Clashing Perspectives: Cannabis Users and Swedish Drug Policy. In: Retreat or Entrenchment? Drug Policies in the Nordic Countries at a Crossroads, edited by Henrik Tham, 267-290. Stockholm: Stockholm University Press, 202 I. DOI: https://doi.org/Io.I6993/bbo.k. License: CC BY 4.o. 
when they meet. We will try to answer a series of questions: How is youth cannabis use perceived by different actors in treatment? How do cannabis users view their use and the measures taken against it? What do motives for using cannabis say about the political context in which they are expressed? In asking these questions, we scrutinize what happens when different perspectives on cannabis use meet and how societal efforts towards change shape this meeting.

We aim to discuss the situation for cannabis users in the Swedish drug policy context, which relies on criminal control and prohibition. We focus on the way this strict policy sets the stage for the encounter between cannabis users and the demands on them to stop using. Starting out with findings from a research project on users like Hektor, as well as youth treatment centers targeting cannabis users, we take a comprehensive look at how these relate to each other. On a more general level, we also discuss what implications these findings have for how the cannabis issue is enacted in policy and practice in Sweden.

The material described in this chapter comes from a research project about cannabis (FORTE, project $\mathrm{nr}$ 2OI 5-OI 582 ). Data was collected from 20I 5-20I7 and consists mainly of interviews. Interviews were carried out with staff from outpatient treatment centers for young substance users in the Stockholm area $(\mathrm{n}=\mathrm{I} 8)$, with young people who have been in treatment at such centers $(\mathrm{n}=\mathrm{I} 8)$, and with adults who use cannabis $(\mathrm{n}=\mathrm{I} 2)$. We also collected online posts $(n=238)$ on this issue through an open discussion thread at Flashback Forum (see https://www.flashback .org/t2883872). The analyses of the different materials were similar. In order to create an overview, a first coding focused on how participants talked about cannabis use, treatment and Swedish drug policy. The data were then, in a second step, coded using various theoretical tracks, including logics (McPherson \& Sauder 20I3), legitimation (Suchman I995), responsibilization (Trnka \& Trundle 20I4) and motive accounts (Burke I969/I945). The materials, including survey data, have previously been analysed separately and presented in empirical articles (Ekendahl, Karlsson \& Månsson 2018; Ekendahl, Månsson \& Karlsson 2020a, 202ob; Karlsson et al. 2018, 2019), including an overview in Swedish 
(Ekendahl, Månsson \& Karlsson 2020c). More information on theoretical and methodological issues can be found in the published articles.

\section{The Framework of a Strict Drug Policy}

In Sweden, cannabis is a controversial and much debated topic in the media and in politics, as well as among authorities and the public. Common viewpoints are that cannabis is particularly dangerous for the psychosocial development of young people (e.g. Danielsson, Olsson \& Allebeck 2019), that it works as a gateway to 'hard' drugs (e.g. Ellgren, Spano \& Hurd 2007) and that it feeds organized crime in problem-burdened areas (e.g. The Swedish Police Authority 20I7). Although cannabis use is uncommon in Sweden compared to many other European states (EMCDDA 20I9), a recurrent claim is that it is increasing among both adolescents and young adults. While young Swedish cannabis users can mainly be seen as 'marijuana testers', with a comparably affluent social situation (Karlsson et al. 20I9), the focus on prevalence as a problem in its own right is common in Sweden (see, e.g., Månsson \& Ekendahl 20I 5). This was recently illustrated in discussions following the increase last year in adult (aged 30-44 years) consumption from I.I\% in 2004 to $3.7 \%$ in 2018 (Public Health Agency 2019), which has attracted some attention (e.g. CAN 20I9; Ritzén 2019).

It is clear that the Swedish restrictive drug policy constitutes an ideological framework when the consequences of cannabis use are described in Sweden. The policy assumes that the substance in itself causes the aforementioned problems (see Chapter 6 by Tham 'On the Possible Deconstruction of the Swedish Drug Policy'). Historically, this focus, to a considerable extent, has been influenced by the work of one of the most important actors in the development of Swedish drug policy, Nils Bejerot, doctor in social medicine (Edman 20I2). Bejerot saw drug use as a contagious disease that needed to be contained in order to prevent societal disaster. His tenets steered policy 'to a police-oriented strategy whose objective was to clear the streets of drug pushers' (Lenke \& Olsson 2002: 69). In line with this policy direction, Sweden does not seem to be heading towards retreat, that is, a more liberalized drug 
policy. Such policies can be seen in the majority of other Western states, and they are usually based on a division between drug use per se and problematic drug use. Rather, recent political moves in Sweden point to doing 'more of the same'. For example, in the Swedish government's strategy for alcohol, narcotics, doping and tobacco it is stated that Sweden shall promote restrictive cannabis policies (Skr. 2015/16:86), and the Swedish Prime Minister Stefan Löfven declared in 20I9 that Sweden should not 'legalize and legitimize [cannabis], and say that this is a natural part of our society. Because it is not, and it should not be' (Olsson 20I9).

Swedish drug policy classifies all drug use as 'abuse' (missbruk). Harm reduction has typically been considered incompatible with the zero-tolerance approach to drugs and is accused of sending the 'wrong' message. While some harm reduction efforts have been developed and made more accessible to drug users in Sweden (e.g. substitution treatment, exchange of syringes and prescribing antidote to opioid overdoses), these are exclusively directed towards 'hard' drugs. Cannabis treatment focuses instead on recovery with abstinence as the end goal. This recovery-as-abstinence model has been debated in other countries (such as the UK and Australia, see e.g., Klein \& Dixon 2020; Lancaster, Duke \& Ritter 20I 5), and it has been suggested that this model has negative implications for individuals seeking to engage in treatment (e.g. McKeganey 20I4; Wincup 20I6). Recent social science drug research has begun to problematize the demands placed upon the drug-using individual to change in order to become 'normal' (e.g. Fomiatti, Moore \& Fraser 20I9; Fraser \& Ekendahl 2018). One central point is that such change-oriented efforts individualize drug problems; another is that rigid definitions of successful treatment outcomes reject some users' wish to continue using drugs, or to change in a different way than what society demands (Pienaar et al. 20I7). As the processes of change related to drug use are complex (e.g. McIntosh \& McKeganey 2000; West \& Brown 20I3), a strict abstinence goal may reinforce feelings of stigmatization among help-seeking individuals who do not agree with this prescribed way out of drug use (Csete et al. 20I6).

The notion of change is usually closely connected to people who use drugs - they are expected to submit themselves to treatment 
and adjust to punitive social welfare measures (e.g. urine tests). However, recent developments in international drug policy have entailed new questions on how treatment systems, legal processes and health promotion might be reformed to benefit people who use drugs. In line with this, scholarly discussions on the meanings of change are surfacing through questions regarding how drugs are made a problem (e.g. Bacchi 20I8), on what the persistent focus on the future creates (e.g. Lancaster, Rhodes \& Rance 2019) and what we might learn from stasis (e.g. Dennis 2019). It is from this theoretical perspective of change that we discuss the findings from some of our previous research on cannabis.

\section{Different Perspectives on Cannabis}

In a previous dissertation project, one of us examined the assumptions about cannabis that are represented in official contexts, such as in the media and at information conferences organized by authorities, and in unofficial contexts, such as on internet forums (Månsson 20I7). The study showed that actors in these discussions relied on scientific evidence showing how dangerous or harmless the substance is. The expansive research literature, however, points in different directions regarding the consequences of cannabis use and how the substance should be regulated (Hall \& Lynskey 2020). The positions are locked between those who advocate continued prohibition and those who want society to liberalize cannabis policies; all think they are right and refuse to reconsider their positions. This also means that cannabis is attributed with divergent meanings; for example, it can symbolically 'become' a threat to a whole youth generation, a medicine or a healthier intoxicant than alcohol.

Here, we look closer at how political conditions, taken for granted 'truths' and societal efforts to get people to avoid the substance are interwoven. Our focus is on how the complicated cannabis issue is expressed in people's descriptions of what they do, think and feel. By engaging with a diversity of knowledge, we hope to avoid the pitfalls of viewing evidence as simplified and the idea of there being 'correct answers' to complex policy questions (Rhodes \& Lancaster 20I9). 


\section{Treatment Perspectives on the Dangers of Cannabis Use}

Although the treatment centers that are included in this study treat all types of substance use (including alcohol), the focus on cannabis was apparent in the staff interviews (Ekendahl, Karlsson \& Månsson 2018). The staff expressed great concerns about the substance. This held true both in relation to the negative consequences that young users were considered to be particularly sensitive to, and to the liberal attitudes that were said to affect them via popular culture and the internet. Concerns about young people's behavior were also key in staff statements. For example, they described cannabis use as dangerous and impossible to combine with a healthy and normal lifestyle. This is illustrated in the quote below where one of our participants elaborated on why she thinks using cannabis is 'a bad idea when you are young':

You have to be clear about what we know about the consequences of smoking cannabis regularly, over extended periods of time. Nothing happens after trying two or three times, but I think that at least parents should know what happens when a young person smokes regularly, and the kids themselves should know. [...] For example, the THC release curve. I talk about it being fat soluble, that it stays in the body a bit longer. I talk about chronic intoxication, although I don't use that word. But I talk about the fact that if you smoke regularly for a long period of time, you're under the influence even when you're not high, so to speak. To the parents, at least, I show brain images demonstrating where in the brain it sticks, the cannabinoid system and things like that.

Here, the effects of regular use are linked to those of sporadic use, which served to emphasize the problem and fuel the concern for young people (regardless of their involvement with cannabis). The concern was made trustworthy by presenting the dangerous effects of cannabis use in biomedical language (e.g. the effects on brain function). The participant drew on scientific evidence of the negative effects of regular cannabis use on young people and used this knowledge to prevent cannabis experimenters from continuing. This process had two effects: it constituted cannabis as particularly dangerous for young people and, in doing so, constituted young people as a group with great needs.

The use of biomedical language was common among staff, and they repeatedly referred to research and statistics to demonstrate 
that they conveyed 'safe' and 'correct' information about cannabis to young people and their parents. This was illustrated by one of the participants in the quote below.

I see this as a very important job that we have to do, since I don't see legalizing yet another drug as a solution. I see it as a very important job over the next few years to provide alternative information - from safe sources and to learn to resist the other stuff. To show another side, that smoking does have negative effects.

The use of research emphasized the severity of the cannabis problem and placed weight on the centers as experts and advocates of zero tolerance to drugs. Scientific evidence thus became a way to both legitimize the treatment and to quality control it. This quote also illustrates how scientific evidence, often presented as a singular 'fact', was used to resist the opinion that cannabis should be legalized (see also Månsson \& Ekendahl 201 5 ).

However, references to science were also problematized by staff. For example, several participants mentioned that some clients referred to scientific reports supporting a different view on cannabis than the one presented by the treatment staff and the strict Swedish drug policy. And as one participant stated, the 'mishmash of information that goes against one another is pretty $\operatorname{mad}[. .$.$] and it is difficult to handle the global opinion when you$ are sitting in a small room with a teenager and you are not $100 \%$ sure of what is really true.' This shows how controversies around evidence created problems, and accordingly the staff avoided going into political discussions as this was seen as a dead end. Similarly, they described how they tried to avoid talking to young people about drug policy and the fact that cannabis is prohibited. This topic was saved for occasions when staff really wanted to emphasize the dangers of the drug and the legal consequences that consumption could lead to.

Throughout, the staff described a competent and serious client work. They referred to their vast experience of meeting young people, and the knowledge of their behavior and needs that they had gained through this. They expressed a clear wish to meet clients 'here and now' in order to personalize efforts and interventions. Each meeting was seen as important for building relationships, providing accurate information about cannabis, and thereby 
facilitating behavioral change. Given this professional approach, the drug political focus on control and abstinence was sometimes described as problematic. The quote below is an example:

It's as if I play a role and I get a lot of transference, like projections. It's as if I'm not a person but I also become the state. There is this young person and every time I see him he talks about it like: 'You all force me to come here and leave urine samples, you all force me to do this!' And I go: 'It's me, who is sitting here as a person talking to you, and I want you to take a drug test.' But all the time it's just 'You all ...'

This quote exemplifies how mandatory parts of the treatment, like urine tests, were described to create resistance and problems in establishing a relationship with the client. The participant here was uncomfortable with being reduced to a representative of the state and to tackle this, she downplayed it by stating that 'I want you to ...' rather than accepting the accusation 'you all force ...' Similarly, the demand to become drug free in treatment was sometimes described as problematic when focusing on relational aspects.

Yes, the way we see it is that you have to become drug free. But I think we are very good at not making it into morals. I think we are good at understanding what is going on. No, it's not always simple, but you don't have to make the decision to never smoke again. [...] But can we make a deal? These six weeks you won't smoke. [...] We start here, and then when you haven't smoked for a while you might see things differently.

Just like mandatory urine tests were transformed into a help offering in the previous quote, becoming drug free is in this quote transformed from a goal imposed from above to a deal made between two equals. Such strategical redefinitions of the situation, from one of compulsion to one of opportunity, were significative of how the staff handled the clash between Swedish drug policy and providing adequate treatment.

One dilemma raised by the staff was that the treatment seemed more suited to help certain groups of clients, even though the stated objective was to make all types of young people quit cannabis. According to the staff, good results could mainly be achieved 
among the clients who could be characterized as 'marijuana testers' (see Karlsson et al. 20I9). More experienced and socially vulnerable users were often seen as more difficult to treat. This observation was also consistent with how the young people themselves perceived the potential of treatment.

\section{Youth Perspectives on Cannabis Use}

The young people we interviewed described different pathways into treatment. Some had entered voluntarily, some were forced to go by parents or school, while others had been court-ordered. Four different user groups could be identified from the client interviews (Ekendahl, Månsson \& Karlsson 2020a). We classified these groups inductively from the study sample as a way to get an overview of the material. One such group was those who described themselves as socially established and saw cannabis use as a stupid mistake - a youth sin. Another group described very problematic backgrounds, containing more deviant behaviors than the use of illegal drugs. Yet another group described cannabis as a lifestyle - they really liked the substance and did not see any problems with it. The last, and least common group, had tried cannabis and gotten caught but did not really think the drug was particularly interesting.

Those who thought that the treatment had been helpful came mainly from the first two groups. They agreed with the staff's descriptions of harms; cannabis controls the behavior of young people and creates an addiction, and they could thereby understand their past. Their own cannabis experiences were similar to those told by the staff at the treatment centers, focusing on, for example, addiction. Metaphors about being inside a 'glass bulb' while using cannabis and about 'being in love' with the substance surfaced repeatedly in both materials. The young clients described how they had been able to embrace the new information they got during treatment and made the decision to stop using cannabis. They saw the treatment as a turning point in life and believed it was easy to take responsibility and change after their contact with the treatment center.

They [staff] have taught you why it's better not to do it [cannabis], than to do it. And I've thought about why you become addicted. 
That the level of happiness rises, and then it sinks below what's normal, below the normal level of happiness that I have now sitting here. You go below a certain point. He [staff] drew some graph showing me. And it confirmed that you can become addicted to this.

The young person who provided the above quote described it almost as a revelation when he, after receiving informative explanations from the staff, realized that his continued use of cannabis was a result of the substance itself. In this and similar descriptions, individual choices, actions and emotions were shaped by the agency of the substance. Later in the interview this topic was revisited, and the client described being able to control his use before coming to treatment, but then becoming convinced he could not. Pivotal in this, and similar stories, was the knowledge passed on by staff about addiction and the brain, which was said to support the client in making the right decision (see also Barnett et al. 20I8). The treatment center here became an 'educator towards “good" risk choices' (Kemshall 2002: 43), and this client was the perfect example of a well-educated citizen who made the choice required by a government actor - to stop using cannabis.

The last two groups generally described resistance to the treatment; they did not think it was something suitable for them and did not see the point at all. They disagreed with the staff's problematization of cannabis and resisted being treated as drug addicts. These young people saw their cannabis use in a completely different way than the treatment staff (e.g. they described it as unproblematic and informed), and were surprised of the medical language used when staff talked about cannabis. These young people questioned the treatment but, because they had committed a crime, they understood and accepted their situation. The treatment was presented as unavoidable in the endeavor to eventually be left alone and to be able to continue with cannabis or to simply get on with their lives. Some described how they 'used' the treatment centers as a way of proving to their families that they were drug free, although they were not (or were only during treatment). They stated that they acted like motivated clients while in treatment in order to continue using cannabis without causing too much trouble, like one of the participants quoted below who had 
been mandated to treatment as a consequence of being caught by the police with traces of THC in his urine.

Participant: They [staff] were more like, 'What can you do to not keep on doing it [cannabis]?' It was basically that question, but in different versions all the time. How they should keep me away from it. Which I did during spring, until the day I quit treatment. [...]

Interviewer: What do you think they would say at the treatment center if they knew that you didn't stop?

Participant: Well, they would be disappointed. I can see their faces right now. Because they have a very clear view that this is bad in every way. But I think cannabis, and this is always my counter-argument, I think that you become slow and stuff, but otherwise I see nothing dangerous with it besides it being illegal. That's the greatest danger.

As mentioned as a key technique for building relationships in the staff interviews, the young person above testified to how staff tried to make him choose to stay away from cannabis, conveying that treatment was not framed as coercion. The participant described his awareness of this, as well as what treatment staff thought about cannabis and what he was obliged to do in treatment. He resisted this, however, in two ways: he took up cannabis use on the day of his release from treatment, and he refused to change his mind about cannabis being rather harmless. However, later in the interview he stated that he avoided voicing such opinions during treatment as any such talk that 'slipped through' made treatment more intrusive, for example through additional urine tests. Thus, the meaning that these young people attributed treatment with seemed to have little to do with the goal of recovery. At the same time, their resistance may not have been visible for treatment staff. In the end, clients with this dodging stance may therefore be taken as illustrative examples of successful rather than poor treatment outcomes.

Whether the young people described resistance or compliance with treatment, they understood their own experiences in a 
responsible manner. For example, information on and assessments of risks were considered to be crucial for their approach to cannabis. They did not refer at all to traditional sociological or pathological explanations of drug use (e.g. economic vulnerability, peer pressure, boredom) when they explained why they had ended up in their current situation (see Järvinen \& Ravn 2015; Phoenix \& Kelly 20I3). Instead, they were careful in describing how they themselves had made the choice to start using, and that no one else was responsible. Regardless of the attitude towards the treatment, the youth generally understood why the adult world was worried about them and they agreed with the basics of strict Swedish drug policy. Although many saw the benefits of legalizing cannabis for medical purposes, they thought differently about legalization for recreational use. The idea was that cannabis is, after all, associated with certain risks that most people cannot handle safely.

\section{Adult Perspectives on Using Cannabis in a Strict Drug Policy}

The young people's relatively compliant approach to Swedish drug policy was not at all visible when the adult cannabis users made their voices heard (Ekendahl, Månsson \& Karlsson 202ob). The online discussions and interviews with adult users showed that prohibition and sanctions against cannabis, as well as stigmatization of users, were seen as unfair, undemocratic and irrational. The adult participants were not classified into different groups, instead we focused on classifying their motives for using the substance. The following quotes thus represent general trends in the material.

We are extremely oppressed, which has made me believe that some get paranoid simply because others cannot know anything about our use. Your whole world can get shattered if the wrong person gets to know about it. Tainted criminal record, extreme difficulties (if not impossible) to get a loan, employers will deny me work etc. The list goes on and on.

As illustrated in the above quote from the online material, most participants were extremely offended by the strict Swedish drug policy and the effects it had on their lives. Both online discussions 
and interviews centered on aspects of stigmatization, problems with how Sweden handled cannabis users and worries about having to deal with criminals to purchase the substance. Accounts of feeling alone, unsafe and hunted by society were repeated. These discussions, for example, centered on experiences of not getting the medical care that was needed after admitting to the use of cannabis, and on stories of young people whose lives had been ruined after police crackdowns. As an effect, some stated that they had lost their faith in Swedish society - calling it 'an oppressive regime - a non-democracy'.

The agitated feelings about Swedish drug policy probably emanate from clashing perspectives on what cannabis is. According to the adult users, cannabis is a relatively harmless substance that could be used for many different purposes; with everything from recreational motives such as relaxation and creativity to medical motives to mitigate physical and mental disorders being mentioned (see also Mitchell et al. 20I6). A common view was that they did not want to change into non-users. With the exception of the effects of the strict drug policy in itself, most did not experience any problems with their use. In fact, it was often described as quite the opposite - it was something that helped them with various problems in life. About half of the participants in the online material referred to medical motives for cannabis use. We could also see, in the interviews, that these motives usually surfaced immediately, to be complemented with accounts of recreation later on when the participants were 'warmed up' and had received follow-up questions. The way the participants approached the question of why they used cannabis thus suggests an influence of drug prohibition on motive accounts - those motives that were believed to be more accepted and rational appeared first. The extract below is an illustration of this:

I had a few friends over. We were going to a reggae club and everybody was there. Five hundred people dancing and having fun. Then I came home, and the police had busted the door open and torn up the apartment. And found ten grams of weed. And I said: 'Oh my god, how can you bust the door open? Why didn't you call?'. 'We did, but you didn't answer.' 'No you didn't! Check my phone.' I don't know what will happen with it. I have been to 
a hearing and I've told them exactly how it is. 'Well, this is it: I smoke. It's for pain and it's relaxing for me.'

Here, the recreational motive of having fun was reformulated into a medical motive of pain relief when the participant described his contact with the police. What is also interesting with this quote is that it was one of very few descriptions of large social gatherings that included cannabis use. Unlike results from prior research describing cannabis use as a social activity (see, e.g., Osborne $\&$ Fogel 2008), the participants did not present this as particularly relevant in Sweden. Instead, they generally claimed to hide their cannabis use from outsiders and do it privately. Some participants even said that a consequence of their cannabis use was that they felt lonely since they were scared to talk to other people about it. While this may be a typical characteristic of adult cannabis use, it may also reflect a drug policy where cannabis use is met as deviant, and where individuals worry about legal sanctions.

Although social settings were not emphasized in the material, the setting was described as important in relation to accounts of more private use of the substance.

When the family came and it was more everyday routines, when you have less time for everything, then I get easily annoyed and I act out. [...] Then I can have a hit [of cannabis], and then I come down and become calm so I can handle the situation. So, my need for cannabis increases when I enter stressful everyday environments.

This quote illustrates how cannabis use was described as an extension of the family setting with its routines, stress and arguments. In this, and similar quotes, drug effects such as intoxication were downplayed or rejected. Cannabis use was instead explained with reference to its soothing effects that facilitate social functioning. These adults recognized that cannabis use violated society's rules - particularly those who used it in family settings. The difference from the young users was that the adults could easily justify their lifestyle by claiming that cannabis made them into (what they perceived as) better people, leading productive and healthy lives. Cannabis use was presented as a conscious decision, similar to how some young persons described it. 


\section{Cannabis, Drug Policy and Change}

Based on the overall results of this study, we, like previous research (e.g. Månsson 20I7), can see that cannabis is a substance with many meanings. Treatment staff and certain groups of young people emphasized its dangers, while other user groups (both young people and adults) described the substance as relatively harmless with both recreational and medical uses. Our research project shows that there is not one unchallenged 'story' about cannabis. To the contrary, all actors in our material seemed to have to explain their views. Not surprisingly, those who presented cannabis as harmless were forced to motivate their stance because it challenged dominant assumptions in Sweden. Perhaps more surprisingly, those who viewed cannabis as dangerous strived to introduce both research and experience to justify this. This shows how the context provides the boundaries as to what can be said about drugs and their users, and that such statements can be understood in relation to both the current strict drug policy and an increasingly drug-liberal world.

This cohesive grip on the material from our research project illustrates how a focus on change shapes the meeting between cannabis users and the drug policy system on several levels - and that it may be helpful for some but problematic for others. Looking at the everyday treatment practice, the demand on young clients to quit using steered the direction of both interventions (e.g. mandatory urine tests) and client-staff interaction (e.g. pedagogical efforts to make young people choose wisely). In this way, the drug played a key role in client relationships and in how these were enacted and legitimized. The treatment was prompted by youth cannabis use and it targeted the effects of the substance. For the large group of 'marijuana testers', this approach was considered to work well. Staff described them as compliant clients who quit using the drug, which indicates good treatment outcomes. The smaller group of more socially disadvantaged and advanced users - who showed several other problem behaviors and were more convinced that cannabis was relatively unproblematic - was considered more difficult to build relationships with and to guide in the direction of lifestyle change. While we have shown that 'difficult' clients can be satisfied with and benefit from the treatment (Ekendahl, Månsson 
\& Karlsson 2020a), this generally reflects that a narrow and judiciary entry into young people's lives (that cannabis use is illegal and must end) has both advantages and disadvantages if the goal is to reduce drug problems. Socially affluent young people who had a lot to lose seemed to listen to staff messages about how dangerous cannabis is and quit use. Those, on the other hand, who had more severe problems in life than consequences of cannabis use often seemed to find it difficult to engage with a treatment they found misdirected and irrelevant. In the worst case, this means that the young people who need the help the most will reject it.

The cannabis problem is usually described through the monitoring of prevalence rates. By such quantification, a complex phenomenon is simplified and made into a distinct problem to be acted upon by society (Lancaster, Rhodes \& Rance 2019). For example, the logic underpinning the vision of a drug-free society, along with the criminalization of personal drug use (see Chapter 6 'On the Possible Deconstruction of the Swedish Drug Policy'), is based on the idea that users have to change into non-users. It also rests on the notion that society has to change from one with illegal drugs to one without. By focusing so strongly on prevalence figures, there is a real risk that Swedish cannabis prevention addresses symptoms of unfavorable living conditions rather than on their root causes. An overly narrow view on people's drug use can also further stigmatize the most socially vulnerable. Being prosecuted for a drug offense may, on the one hand, help some individuals to get on the right track (Ekendahl, Månsson \& Karlsson 2020a). On the other hand, it can also impose an identity such as 'drug addict' or 'junkie' on young people who, under different circumstances, might 'mature out' of experimentation with drugs. The material effects of this labelling can be profound, as illustrated by users who describe that they have lost their jobs, not received proper medical care and in some ways live as outcasts. Although the Swedish welfare state strives for inclusion (Moore et al. 20 I 5), the current drug policy with its 'change agenda' may exclude cannabis users as 'Others'.

Research shows that those who are defined by society as drug users are forced to fight hard to escape the stigma and marginalization that this label entails (e.g. Ekendahl 2006; Fraser et al. 
2017; Petersson 2013; Svensson 1996). As illustrated in this research project, some cannabis users simply do not identify with being a problem that needs to be solved. They want to continue using their drug of choice for both medical and recreational reasons, and they view society's demands for change as problematic. By paying attention to users who say they benefit from their use, and by engaging with their wishes to change slowly, or not at all, we may develop a treatment and policy approach that is more responsive to the perspectives of those who we wish to help. This, however, seems difficult if the issue of cannabis is governed by a primary focus on change. We therefore ask, what would happen if we were to accept that cannabis (and other drugs) are part of our society? Such an approach would perhaps transform the demand to change quickly (for example in treatment) and provide the possibility of slowing down and paying attention to the experiences and preferences of the users. This could perhaps direct the focus on change from the substance and the users towards more general societal aspects of wellbeing. As suggested by Fomiatti, Moore \& Fraser (2017), this would help in developing more sensible and humanitarian treatment and policy.

In conclusion, despite the increased demands on evidence-based practice, it seems difficult to progress in the discussions on cannabis by relying on objective knowledge. We have previously shown how diametrically different views on what cannabis is, how the drug should be controlled and whether the user group should be considered large or small find research support (see, e.g., Månsson 2017), which indicates that sources are chosen based on the interests of different parties. Such controversy highlights fundamental uncertainties of 'science-making' and the problem of relying on evidence as a singular entity that can unanimously guide policy (see, e.g., Rhodes et al. 20I9). In our different materials, cannabis appears fluid with multiple meanings. Consequently, the problems related to the substance become very different. For example, to the staff, the effects of cannabis on the brain were pivotal, while the adult users generally emphasized the punitive measures taken against them. A multitude of actors with different perspectives and agendas are engaged with the problem, which in turn can introduce a variety of themes for discussion. With different 
problematizations, various scientific results become relevant and these results are also negotiated in practice between professional opinions and political ideas that show 'how evidence is made to work' (Rhodes et al. 2019).

Following these considerations, we believe that cannabis should be seen as a matter of concern rather than as a matter of fact (Latour 2004); it encompasses a variety of voices and knowledge. There seems to be nothing fundamentally scientifically rational when Swedish politicians follow the prohibitionist tradition without considering alternative, and increasingly endorsed, ways of controlling cannabis (see Goldberg 202I). But how are we then to combine and weigh different perspectives against each other? In line with Rhodes and Lancaster (2019), we find it relevant to seriously elucidate how evidence is made, put to use and made to matter. Simply stating that research shows that cannabis is dangerous and should therefore be prohibited becomes pointless when very diverse claims can be supported by scientific studies; cannabis is not merely a technical and a scientific problem but also a social and a political one. Such a complex issue requires complex solutions. Another approach would be to take seriously and clarify how politics, ideology and science interact when societies define and solve drug problems (Bacchi 20I8). Engaging with the uncertainty of what cannabis is, and taking different actors and their controversies seriously, might not establish a 'truth' about cannabis, but it can make the situation more intelligible and reveal aspects that were initially difficult to see (Callon, Lascoumes $\&$ Barthe 2009). It could result in our decision-makers feeling obliged to justify a continued focus on cannabis-using young people and a continued criminalization of drug use with reference to sources other than research findings supporting this policy.

\section{References}

Bacchi, C. (20I8). Drug problematizations and politics: Deploying a poststructural analytic strategy. Contemporary Drug Problems, $45(\mathrm{I}), 3-\mathrm{I} 4$.

Barnett, A. I., Hall, W., Fry, C. L., Dilkes-Frayne, E. \& Carter, A. (20I8). Drug and alcohol treatment providers' views about the 
disease model of addiction and its impact on clinical practice: A systematic review. Drug and Alcohol Review, 37(6), 697-720.

Burke, K. (I969/I945). A grammar of motives. Berkeley: University of California Press.

Callon, M., Lascoumes, P. \& Barthe, Y. (2009). Acting in an uncertain world: An essay on technological democracy. Cambridge, UK: MIT Press.

CAN. (2019). Drogutvecklingen i Sverige 2019 [Drug development in Sweden 2019]. CAN rapport I 80. Stockholm: CAN, Centralförbundet för Alkohol- och Narkotikaupplysning.

Csete, J., Kamarulzaman, A., Kazatchkine,M., Altice, F., Balicki, M., Buxton, J., Cepeda, J., Comfort, M. Goosby, E., Goulão, J., Hart, C., Horton, R., Kerr, T., Lajous, A. M., Lewis, S., Martin, N., Mejía, D., Mathiesson, D., Obot, I., Ogunrombi,A., Sherman, S., Stone, J., Vallath, N., Vickerman, P., Zábranský, T., \& Beyrer, C. (20I6). Public health and international drug policy. The Lancet, 387(I0026), I427-I480.

Danielsson, A-K., Olsson, P. \& Allebeck, P. (2019). Cannabis: Harmlös recreation eller farlig drog? [Cannabis: Harmless recreation or dangerous drug?]. Stockholm: Forte.

Dennis, F. (2019). Mobilising stasis: A critical orientation to change. Conference presentation at Contemporary Drug Problems Conference, Prato, Italy, 4-6 September 20 I 9.

Edman, J. (2OI2). Vard och ideology: Narkomanvården som politiskt slagfält. [Treatment and ideology: Addiction treatment as a political battlefield]. Umeå: Boréa Bokförlag.

Ekendahl, M. (2006). Why not treatment? Untreated substance abusers' accounts of their lifestyles and efforts to change. Contemporary Drug Problems, 33(4), 646-668.

Ekendahl, M., Karlsson, P. \& Månsson, J. (2018). Logics of legitimation in Swedish treatment for youth cannabis use: The problem representations of social workers in a prohibitionist policy context. Contemporary Drug Problems, 45(3), 244-26I.

Ekendahl, M., Månsson, J. \& Karlsson, P. (2020a). Risk and responsibilization: Resistance and compliance in Swedish 
treatment for youth cannabis use. Drugs: Education, Prevention and Policy, 27(I), 60-68. https://doi.org/I0.I080/09687637.20I 8 .I 544224 .

Ekendahl, M., Månsson, J. \& Karlsson, P. (2020b). Cannabis use under prohibitionism - the interplay between motives, contexts and subjects. Drugs: Education, Prevention and Policy, 27(5), $368-376$.

Ekendahl, M., Månsson, J. \& Karlsson, P. (2020c). Cannabis i Sverige - en komplex substans, en enkelspårig drogpolitik? Socionomens Forskningssupplement, 47, 16-25.

Ellgren, M., Spano, S. M. \& Hurd, Y. L. (2007). Adolescent cannabis exposure alters opiate intake and opioid limbic neuronal populations in adult rats. Neuropsychopharmacology, 32(3), 607-6I 5.

EMCDDA [European Monitoring Centre for Drugs and Drug Addiction]. (2019). European drug report 2019: Trends and development. Luxembourg: Publications Office of the European Union.

Fomiatti, R., Moore, D. \& Fraser, S. (2017). Interpellating recovery: The politics of 'identity' in recovery-focused treatment. International Journal of Drug Policy, 44, I74-1 82.

Fomiatti, R., Moore, D. \& Fraser, S. (2019). The improvable self: Enacting model citizenship and sociality in research on 'new recovery'. Addiction Research \& Theory, 27(6), 527-538.

Fraser, S. \& Ekendahl, M. (2018). 'Getting better': The politics of comparison in addiction treatment and research. Contemporary Drug Problems, 45(2), 87-106.

Fraser, S., Pienaar, K., Dilkes-Frayne, E., Moore, D., Kokanovic, R., Treloar, C. \& Dunlop, A. (20I7). Addiction stigma and the biopolitics of liberal modernity: A qualitative analysis. International Journal of Drug Policy, 44, I92-20I.

Goldberg T. (202I). A path forward for Swedish drug policy? Nordic Studies on Alcohol and Drugs, 38 (2), I I 2-I 24. https:// doi.org/IO.II77/I 455072520978352 .

Hall, W. \& Lynskey, M. (2020). Assessing the public health impacts of legalizing recreational cannabis use: The US experience. World Psychiatry, I9(2), I79-1 86. 
Järvinen, M. \& Ravn, S. (2015). Explanations and expectations: Drug narratives among young cannabis users in treatment. Sociology of Health \& Illness, 37 (6), 870-887.

Karlsson, P., Ekendahl, M., Månsson, J. \& Raninen, J. (2019). Has illicit drug use become normalised in groups of Swedish youth? A latent class analysis of school survey data from 2012 to 2015 . Nordic Studies on Alcohol and Drugs, 36(I), 2I-35.

Karlsson, P., Ekendahl, M., Gripe, I. \& Raninen, J. (2018). Individual and school-class correlates of youth cannabis use in Sweden: A multilevel study. Nordic Studies on Alcohol and Drugs, 35 (2), I3 I-I 46.

Kemshall, H. (2002). Effective practice in probation: An example of 'advanced liberal' responsibilisation? The Howard Journal of Criminal Justice, $4 \mathrm{I}(\mathrm{I}), 4 \mathrm{I}-58$.

Klein, M. \& Dixon, J. (2020). Problematising 'recovery' in drug policy within Great Britain: A comparative policy analysis between England, Wales and Scotland. Journal of Drug Policy Analysis, I3(I), I-I7.

Lancaster, K., Duke, K. \& Ritter, A. (201 5 ). Producing the "problem of drugs": A cross national-comparison of "recovery" discourse in two Australian and British reports. International Journal of Drug Policy, 26(7), 6I7-625.

Lancaster, K., Rhodes, T. \& Rance, J. (2019). 'Towards eliminating viral hepatitis': Examining the productive capacity and constitutive effects of global policy on hepatitis C elimination. International Journal of Drug Policy, 80, I024I9.

Latour, B. (2004). Why has critique run out of steam? From matters of fact to matters of concern. Critical inquiry, 30(2), $225-248$.

Lenke, L. \& Olsson, B. (2002). Swedish drug policy in the twenty-first century: A policy model going astray. Annals of the American Academy of Political and Social Science, 582(I), 64-79.

McIntosh, J. \& McKeganey, N. (2000). Addicts' narratives of recovery from drug use: Constructing a non-addict identity. Social Science \& Medicine, 5 O(IO), I 5 OI-I 5 IO. 
McKeganey, N. (20I4). Clear rhetoric and blurred reality: The development of a recovery focus in UK drug treatment policy and practice. International Journal of Drug Policy, 25(5), 957-963.

McPherson, C. M., \& Sauder, M. (2013). Logics in action: managing institutional complexity in a drug court. Administrative Science Quarterly, 58(2), 165-196.

Mitchell, J. T., Sweitzer, M. M., Tunno, A. M., Kollins, S. H. \& McClernon, F. J. (20I6). 'I use weed for my ADHD': A qualitative analysis of online forum discussions on cannabis use and ADHD. PloS one, II (5), eOI 566 I4.

Moore, D., Fraser, S., Törrönen, J. \& Tinghög, M. E. (20 I 5 ). Sameness and difference: Metaphor and politics in the constitution of addiction, social exclusion and gender in Australian and Swedish drug policy. International Journal of Drug Policy, 26(4), $420-428$.

Månsson, J. (2017). Cannabis discourses in contemporary Sweden: Continuity and change (Doctoral dissertation, Department of Social Work, Stockholm University).

Månsson, J. \& Ekendahl, M. (2O I 5). Protecting prohibition: The role of Swedish information symposia in keeping cannabis a high-profile problem. Contemporary Drug Problems, 42(3), 209-225.

Olsson, H. (2019, August I3). Löfven: De rikas knarkande göder gängkriminaliteten [Löfven: The drug use of the rich is feeding gang criminality]. Dagens Nyheter. Retrieved from: https://www .dn.se/nyheter/politik/lofven-de-rikas-knarkande-goder-gang kriminaliteten/.

Osborne, G. B. \& Fogel, C. (2008). Understanding the motivations for recreational marijuana use among adult Canadians. Substance Use \& Misuse, 43(3-4), 539-572.

Petersson, F. (2013). Kontroll av beroende. Substitutionsbehandlingens logik, praktik och semantik [Control over addiction. The logic, practice and semantics of substitution treatment]. Malmö: Egalité.

Phoenix, J. \& Kelly, L. (20I3). 'You have to do it for yourself': Responsibilization in youth justice and young people's situated 
knowledge of youth justice practice. The British Journal of Criminology, 53(3), 4I9-437. https://doi.org/IO.I093/bjc/azso78.

Pienaar, K., Moore, D., Fraser, S., Kokanovic, R., Treloar, C. \& Dilkes-Frayne, E. (20I7). Diffracting addicting binaries: An analysis of personal accounts of alcohol and other drug 'addiction'. Health, 2 I (5), 5 I9-537.

Public Health Agency. (2019). Cannabisanvändning i befolkningen [Cannabis use in the population]. Retrieved from: https://www .folkhalsomyndigheten.se/folkhalsorapportering-statistik /tolkad-rapportering/folkhalsans-utveckling/levnadsvanor /cannabisanvandning-i-befolkningen/.

Rhodes, T. \& Lancaster, K. (20I9). Evidence-making hepatitis C cure: Towards a science that knows more carefully. International Journal of Drug Policy, 72, 40-46.

Rhodes, T., Lancaster, K., Harris, M. \& Treloar, C. (2019).

Evidence-making controversies: The case of hepatitis $\mathrm{C}$ treatment and the promise of viral elimination. Critical Public Health, 29(3), 260-273.

Ritzén, S. (2019, September 23). Cannabisbruket ökar bland 30- till 44-åringar [Cannabis use increases among 30 to 44 year olds]. Svt Nyheter. Retrieved from: https://www.svt.se/nyheter/inrikes /cannabisbruket-okar-bland-30-till-44-aringar.

Skr 20I 5/16:86. En samlad strategi för alkohol-, narkotika-, dopnings-och tobakspolitiken 2016-2020 [A cohesive strategy for alcohol, narcotics, doping and tobacco politics 20I6-2020]. Stockholm: Ministry of Health and Social Affairs.

Suchman, M.C. (I995). Managing Legitimacy: Strategic and Institutional Approaches. Academy of Management, 20(3), 57 I -6 IO.

Svensson, B. (I996). Pundare, jonkare och andra: Med narkotikan som följeslagare [Dopeheads, junkies and others: With drugs as companion]. Stockholm: Carlsson Bokförlag.

The Swedish Police Authority. (20I7). Polisens rapport om allvarlig och organiserad brottslighet 2017 . Stockholm: Polismyndigheten, Nationella operative avdelningen. Retrieved from: file:///C:/Users/ekend/AppData/Local/Temp/Polisens \% 20 
rapport $\%$ 200m \% 20allvarlig $\%$ 200ch \% 20organiserad $\% 20$ brottslighet $\%$ 2020I 7-2.pdf.

Trnka, S. \& Trundle, C. (20I4). Competing responsibilities: Moving beyond neoliberal responsibilisation. Anthropological Forum, $24(2)$, I $36-I 53$.

West, R. \& Brown, J. (2013). Theory of addiction. Oxford: Wiley-Blackwell.

Wincup, E. (2016). Gender, recovery and contemporary UK drug policy. Drugs and Alcohol Today, I6, 39-48. 